EPRA International Journal of Economic and Business Review-Peer Reviewed Journal

Volume - 9, Issue -2, February 2021 | e-ISSN: 2347 - 9671| p- ISSN: 2349 - 0187

\title{
AN ANALYSIS OF UNORGANIZED LABOR CLASS: DURING COVID 19 A STUDY WITH REFERENCE TO SELECT SEGMENT IN BANGALORE
}

\begin{tabular}{|c|c|}
\hline 1 & \\
1 & $\begin{array}{c}1 \\
\text { Assistant professor, Department of commerce, } \\
\text { K.L.E. Society's S. Nijalingappa College, } \\
\text { Affiliated to Bangalore Central University, } \\
\text { Rajajinagar. Bangalore-10 }\end{array}$ \\
2Dr. Ravi. B. & $\begin{array}{c}{ }^{2} \text { Assistant professor, Department of commerce, } \\
\text { Government First Grade College, Humanabad. } \\
\text { Dist. Bidar, Affiliated to Gulbarga University } \\
\text { Kalburgi }\end{array}$ \\
\end{tabular}

\section{ABSTRACT}

Article DOI URL: https://doi.org/10.36713/epra6378

An attempt has been made in this paper regarding impact on life of unorganized group of laborers and migrants in the city of Bangalore, especially during the present situation of disaster COVID19 epidemic. Even after being necessary element of the informal part of the economy. These workers are often invisible from the point of view of societal, cultural and political main stream of this global city. The migrant laborers in the city are marginalized from the conventional urban prospect. In this regard analysis of this section was felt essential.

A few essential aspects must be taken to tackle for survival during the epidemic COVID19 deadly disease by the government. From the point of view these workers who are unskilled, semi skilled specially their job depend on contractual or which is in the form of unorganized laborers primarily they are working in automotive, manufacturing, construction industries, and also in hotels, street vendors, auto rickshaw drivers, gardeners and household helpers. The data gathered from personal experiences i.e. primary and from news reports, magazines and other secondary sources to analyze conditions of unorganized labors community in Bangalore city.

KEYWORDS: Unorganized labors, Migrants, Unskilled, Government, Bangalore, Covid 19

\section{INTRODUCTION}

Bangalore always recognized world-wide with its superior performance at enormous history. At beginning COVID-19, the city was popularized as a capable model for other cities to follow while fighting against deadly disease and the subsequent situation of disorder \& uncertainties. First COVID positive case emerged in the city on March 2020. Since then, the Karnataka state government has been cautious in devising plans for efficiently monitoring the crisis situation. Number of people testing positive was mounting. The migrant laborers or workers during lockdown, an inevitable presence in the city space of Bangalore, encounter social exclusion from the mainstream.

The narratives of their severe misery fight for survival against pandemic found incompetence of the government and in adequately representing them within the structure of urban governance and hospitality. With this it is need of time to investigate the problems and difficulties faced by migrant laborers or workers in Bangalore. 
The reason behind an alarming increase in the number of migrant labors or workers,

$>$ They felt sense of frustration on inability satisfy their aspirations was one of the prime factors that enforced the labors relocate to their native place.

$>$ A high percentage of this migrant population was illiterate because of which they were categorized as unskilled laborers, who mostly received employment as contractual or which is in the form un organized labor's.

$>$ Workers primarily they are working in automotive, construction and Production field, and also in hotels, street vendors, auto rickshaw drivers, gardeners and household helpers.

$>$ Basic health and individual sanitation not assured to them due to the lack of concern and responsibility from government officials.

$>$ The workers received nothing from Labor department. Most of inhabitants were working in construction, hotels many families from road side coffee shops, small and tiny huts were shifted to a corporation housing project located two miles away to the edge of the city.

$>$ That's how they were deliberately pushed from growing city and so detached participating from urban decision making. Hence migrant laborers and their social exclusion in Bangalore.

\section{STATEMENT OF PROBLEM}

Semiskilled and unskilled migrant labors though they are part of city the contemporary scenario shows how the image of an immigrant laborer is still unclear in the planning scheme. They are neither given scope nor provided with basic amenities to construct secure and arrangement. Frequently they are pressed away from the center to the edge of the city where medical, educational and other necessary resources are unavailable and remote areas are deprived of electricity, water and sanitation facilities. Labors apparently treated as outsider, they detached from mainstream urban society. Thus it is an essential aspect that COVID 19 added dilemmas in to life of these labors in Bangalore, by dragging far away from the urban societal traditions and practices.

\section{NATURE AND SCOPE OF THE STUDY}

The study is descriptive and analytical in nature. In this paper an attempt has been made to evaluate and describe circumstances during COVID 19. The study is confined to ascertain the fate of unorganized laborers. It is restricted from the point of view Bangalore city.

\section{OBJECTIVES OF THE STUDY}

$>$ To evaluate problems and issues, related to unorganized labors during covid-19 in Bangalore.

$>$ To identify radically affected, economic activities up on whom livelihood of these people dependent.

$>$ To ascertain legitimate action to be taken by the Government for wellbeing of unorganized segment labors during crisis.

$>$ To ascertain measures adopted by the Government to avoid migration of during covid-19 from Bangalore.

$>$ To offer suggestions based on findings of our study.

\section{HYPOTHESYS OF THE STUDY}

H0: There is no significant relationship between earnings of the labors during covid crisis and normal period.

H1: There is a significant relationship between earnings of the labors during covid crisis and normal period.

\section{METHEDOLOGY}

The research is carried on the basis of descriptive and analytical way. By going through the path of objectives set for the study, both primary and secondary data has been collected from news, papers, journal, magazines, internet, and through personal interaction with unorganized labors by using appropriate method and tools. In this context an attempt has been made to evaluate prevailing circumstances during COVID 19. Specifically from the point of view unorganized labors by considering select segment. And study is confined from the point of view Bangalore city only.

\section{AN AIE VIEW: UNORGANISED LABORERS PROBLEMES AND GOVERNMENT MEASURES.}

At the time of lockdown in India beginning on the date of March 25, immigrant laborers were worried regarding jobs, food, shelter \& societal safety. The labors or workers settlements situated close to Kundalahalli Varthur, Marathahalli, and Mylasandra in Bangalore, were in need of essential requirements like food, shelter, clothing, and water since the regional governing agencies unsuccessful to drive them any internal support and assurance from state Government Karnataka. Both native and the host states constrained them from crossing the boundaries, since they had panic of dissemination the infection. The state authority, opened Seva Sindhu website for the labors or workers to enroll their identity, in order to facilitate reach their native places. The women employed at garment factories in Rajarajeswari colony lost their jobs and thus they don't have any source of income to run their family. At the same time government 
hospitals were completely filled with covid19 patients, pregnant women from labor camps found it difficult to find admission even they cannot pay to private hospital charges. Age old women who are supposed receive pension from government post offices and withdraw money they are not been able to do so due to unavailability neither government transportation nor private facilities.

\section{DATA ANALYSIS AND INTERPRETATION}

TABLE-1: CALCULATION OF AVERAGE INCOME ON SKILLBASIS DURING COVID 19.

\begin{tabular}{|c|c|c|c|}
\hline SKILL \& INCOME & SKILLED & SEMI SKILLED & UNSKILLED \\
\hline $\begin{array}{c}\text { Number of laborers, workers } \\
\text { (out of 100 percent) }\end{array}$ & 24 & 41 & 35 \\
\hline Income level During COVID19 & $250-300$ & $150-180$ & $35-55$ \\
\hline AVERAGE INCOME & $\mathbf{2 7 5}$ & $\mathbf{1 6 5}$ & $\mathbf{4 5}$ \\
\hline Income level during normal time & $750-900$ & $450-500$ & $200-250$ \\
\hline AVERAGE INCOME & $\mathbf{8 2 5}$ & $\mathbf{4 7 5}$ & $\mathbf{2 2 5}$ \\
\hline
\end{tabular}

Sources: Data earning potential based on skill, primary.

According to the above table gives the details of the income level of labors based on their skill. It shows that there is an enhancement in the financial status of the immigrant labor after having started working in construction sector. The laborers or workers are happy after having regenerate source of revenue. Plenty of laborers who don't have land were working as agricultural laborers not been able make even two meals in day in their village itself, and now at least they have two meals a day. It is found that the skilled workers i.e. contractors, granite workers, electricians, painters, are earning more than three times of what they were earning earlier. Semi-skilled laborers or workers have nearly doubled their earnings. The unskilled workers led a dismal life since they earned around Rs55 to 75 in day and that also per day basis on which they find a work, on numerous times they not find any work and had to lead life with just Rs. 700 to 800 in a month. After being found work as supportive laborers in the construction site, they are earning at least of Rs 250 in a day.

TABLE-2: INCOME AND SKILL OF UNORGANISED LABORERS DURING COVID19.

(Comparison between skill and income)

\begin{tabular}{|c|c|c|c|}
\hline LEVEL OF SKILL \& INCOME. & SKILLED & SEMI SKILLED & UN SKILLED \\
\hline Number of workers & 24 & 41 & 35 \\
\hline $\begin{array}{c}\text { Average Income level During } \\
\text { COVID19 }\end{array}$ & 275 & 165 & 45 \\
\hline $\begin{array}{c}\text { Percentage of. Income/ compared } \\
\text { workers }\end{array}$ & $\mathbf{5 7}$ & $\mathbf{3 4}$ & $\mathbf{9}$ \\
\hline
\end{tabular}

Source: of income based skill in percentage.

According to the data available in table 2, it can under stood that during the epidemic COVID 19 period skilled laborers or workers earning on an average compared to other working class far better i.e. up to 57 percentage. But at the same time semi skilled working groups are earning comparatively lesser than that of skilled class, i.e. on average up to $34 \%$ towards their lively hood it shows that earning depend skill.
Simultaneously unskilled classes are managed only a meager up to the extent of $9 \%$ only. It is lowest compared to other working groups. With this we can understand that a very big gap between earning potential and level of skill, even we can observe that distress circumstances of all three categories of unorganized labors or working class due this these unorganized laborers migrating to their native places. 
TABLE-3: INCOME AND SKILL OF UNORGANISED LABORERS DURING NORMALCY

\begin{tabular}{|c|c|c|c|}
\hline \multicolumn{4}{|c|}{ (Comparison between skill and income) } \\
\hline LEVEL OF SKILL \& INCOME. & SKILLED & SEMI SKILLED & UN SKILLED \\
\hline Number of workers & 24 & 41 & 35 \\
\hline $\begin{array}{c}\text { Average Income level During } \\
\text { normalcy }\end{array}$ & $750-900$ & $450-500$ & $200-250$ \\
\hline $\begin{array}{c}\text { Average income } \\
\text { Percentage of. Income/ compared } \\
\text { workers }\end{array}$ & 825 & 475 & 225 \\
\hline
\end{tabular}

Source of income based skill in percentage. 1

According to the data available in table 3, it can observed that during the epidemic COVID 19 period skilled laborers or workers earning on an average compared to other working class far enhanced i.e. up to 54 percentage. And at the same time semi skilled working groups are income comparatively lower i.e. on average up to 31 percentage . Towards their lively hood it shows that their income depends up on level of skill. Simultaneously unskilled laborers or working classes are just managing inadequate income up to the extent of 15 percentages only. It is lowest compared to other working groups. With this we can understand that a very big gap between earning potential depend up on level of skill, if we observe the level of suffering during the circumstances. From all three categories of unorganized labors or working class, unskilled laborers are not getting sufficient source of lively hood.

TABLE-4: COMPARATIVE PERCENTAGE DURING COVID-19

\begin{tabular}{|c|c|c|c|c|}
\hline $\begin{array}{c}\text { Serial } \\
\text { Number }\end{array}$ & $\begin{array}{c}\text { Level of Skill \& } \\
\text { Income }\end{array}$ & $\begin{array}{c}\text { Average Income } \\
\text { During COVID19 }\end{array}$ & $\begin{array}{c}\text { Average income } \\
\text { During Normal } \\
\text { Time }\end{array}$ & $\begin{array}{c}\text { Comparative } \\
\text { Percentage }\end{array}$ \\
\hline 1 & Skilled & 275 & 825 & 55 \\
\hline 2 & Semi skilled & 165 & 475 & 32 \\
\hline 3 & Un skilled & 45 & 225 & 13 \\
\hline Total & Working class & $\mathbf{4 8 5}$ & $\mathbf{1 5 2 5}$ & $\mathbf{1 0 0}$ \\
\hline
\end{tabular}

According table-4, Comparative percentage during COVID 19, it can observed average income during COVID 19 amount's to 485, at the same time average income during normal circumstances it was amount's to 1525. Comparative percentage between the groups showing result as skilled 55, semi skilled 32 and unskilled 13 in this context there is declined trend from skilled to unskilled working class.

TABLE-5: AVERGE INCOME DURING COVID-19, INCOME DURING NORMAL TIME

\begin{tabular}{|c|c|c|c|}
\hline $\begin{array}{c}\text { Serial } \\
\text { Number }\end{array}$ & $\begin{array}{c}\text { Average Income During } \\
\text { COVID19 }\end{array}$ & $\begin{array}{c}\text { Average income During } \\
\text { Normal Time }\end{array}$ & Total \\
\hline $\mathbf{1}$ & 275 & 825 & 1100 \\
\hline $\mathbf{2}$ & 165 & 475 & 640 \\
\hline $\mathbf{3}$ & 45 & 225 & 270 \\
\hline Total & $\mathbf{4 8 5}$ & $\mathbf{1 5 2 5}$ & $\mathbf{2 0 1 0}$ \\
\hline
\end{tabular}




\section{ANALYSIS OF VARIANCE RESULT}

F - VALUE $=3.4644$

$\mathbf{P}-$ VALUE $=0.1362$

TABLE-6: DATA SUMMARY

\begin{tabular}{|c|c|c|c|c|}
\hline Groups & N & Mean & Standard Deviation & $\begin{array}{c}\text { Standard } \\
\text { Error }\end{array}$ \\
\hline Group 1 & $\mathbf{3}$ & 161.6667 & 115.0362 & 66.4162 \\
\hline Group 2 & $\mathbf{3}$ & 508.3333 & 301.3857 & 174.0051 \\
\hline
\end{tabular}

TABLE-7: ANOVA - TEST

\begin{tabular}{|c|c|c|c|c|c|}
\hline Source & $\begin{array}{c}\text { Degree of } \\
\text { freedom } \\
\text { D.F }\end{array}$ & $\begin{array}{c}\text { Sum of squares } \\
\text { S.S }\end{array}$ & $\begin{array}{c}\text { Mean } \\
\text { Squares M.S }\end{array}$ & F-Value & P-Value \\
\hline $\begin{array}{c}\text { Between } \\
\text { Groups }\end{array}$ & $\mathbf{1}$ & 180266.5973 & 180266.5973 & & \multirow{2}{*}{0.4644} \\
\cline { 1 - 4 } $\begin{array}{c}\text { With in } \\
\text { Groups }\end{array}$ & $\mathbf{4}$ & 208133.3349 & 52033.3337 & & \\
\cline { 1 - 4 } Total & $\mathbf{5}$ & 388399.9323 & & \\
\hline
\end{tabular}

From the above, Table-4 exhibits skilled working class income on average 55 percentage, skilled working class income on average 32 percentage, at the same time un skilled working class income indicating 13 percentage with this information we came to know that unskilled working class struggling hard to generate their livelihood compared to other two groups.

$>$ It is significant point to note overall performance from the point of view of our study indicating. Table-7 ANOVA Test FValue 3.4644, at the same time P-value 0.1362 percent, since calculated value high compared to $\mathrm{P}$ table value hence, $\mathrm{H} 0$ null hypothesis rejected. And alternative hypothesis is accepted $\mathrm{H} 1$.

\section{FINDINGS OF THE STUDY}

The unskilled workers led a dismal life since they earned around Rs55 to 75 in day and that also per day basis on which they find a work, on numerous times they not find any work and had to lead life with just Rs. 700 to 800 in a month. After being found work as supportive laborers in the construction site, they are earning at least of Rs 250 in a day.

According table-4, Comparative percentage during COVID 19, it can observed average income during COVID 19 amount's to 485, at the same time average income during normal circumstances it was amount's to 1525 . Comparative percentage between the groups showing result as skilled 55, semi skilled 32 and unskilled 13 in this context there is declined trend from skilled to unskilled working class.
From the above, Table-4 exhibits skilled working class income on average 55 percentage, skilled working class income on average 32 percentage, at the same time un skilled working class income indicating 13 percentage with this information we came to know that unskilled working class struggling hard to generate their livelihood compared to other two groups.

It is significant point to note from the point of view of our study indicating. Table-7 ANOVA Test F-Value 3.4644, at the same time P-value 0.1362 percent, since calculated value high compared to $\mathrm{P}$ table value hence, $\mathrm{H} 0$ null hypothesis rejected. And alternative hypothesis is accepted $\mathrm{H} 1$.

The women employed at garment factories lost their jobs and thus they don't have any source of income to run their family.

It is found that in India top richest 1 percent of the big family owned business class and politicians hold 73 percent of the wealth earned by the nation which is comparatively same to the entire budget of central government.

They are neither given scope nor provided with basic amenities to construct secure and arrangement. Frequently they are pressed away from the center to the edge of the city where medical, education.

Labors are invisible, neglected and separated from the conventional metropolitan sight due to some of the factors like gender inequality, provincial, traditional, cultural, and religious sentiments 


\section{SUGGESTIONS}

$>$ An important lesson that the COVID epidemic has taught the policymakers in India is to provide greater momentum to sectors which create better allocation of resources and reduce income inequalities.

$>$ It is a need of the time to provide a social security card with a unique identification number to every citizen of the nation along with a 100 percent financial inclusion.

$>$ Proper measures need be to take in order to avoid migration of working class from urban to native rural places during distress arising out of nature calamity or epidemic like COVID 19

$>$ Government of must encourage basic fulfillment of basic needs and requirements like food, shelter, clothing, and water.

$>$ At the same time government must focus on encouraging women empowerment and adequate employment opportunities towards all sections of people.

$>$ Government agencies must make sure in bring labors not to be treated as outsider, they should not detached from mainstream urban society.

$>$ Labors played a pioneer role in building this world class city which is recognized worldwide since they must be protected by government agencies.

\section{CONCLUSION}

Every crisis brings positive opportunity also in this context it is the time to re-evaluate for the development. Laborers have engaged in metro city of Karnataka Bangalore since form long years, even after that they are deprived from legitimate rights. They played a pioneer role in building this renowned city which is recognized worldwide they are invisible, neglected and separated from the conventional metropolitan sight due to some of the factors like gender inequality, provincial, traditional, cultural, and religious sentiments. Indian economy supposed to face consequence of pandemic covid crisis economist's analyzed shocking loss of US \$120 billion or 4 percent of the GDP. As it has been witnessed inconsistency and total shut down of all economic activities like production, consumption, trade activities in this context unorganized laborers are pushed away from the main stream. Laborer are exploited by the private institutions and denied to pay needed facilities. Unorganized workers need to define their agency and emphasize on their rights to have a distinguished access at center, simultaneously seek social justice and become a significant stakeholder, by preventing social injustice. The need of time is to reestablish those who are marginalized from the heart of the city.

\section{REFERENCES}

1. https://www.thehindubusinessline.com/economy/tra de-impact-of-coronavirus-for-india-estimated-at348-mn-un-report/article

2. Kannan K.P and pillai, vijay Mohanan: Social Security in India: The Long Lane treaded and the longer road Ahead towards Universlization.

3. WHO. (2020) COVID -2019 Situation Reports. Retrieved

fromhttps://www.who.int/emergencies/diseases/nov el-coronavirus-2019/situation-reports.

4. COVID-19: Number of infected contract laborers in Bangalore Metro climbs to 80. 2020 Bangalore Mirror https://bangaloremirror.indiatimes.com

5. Karnataka opens relief centers under lockdown for migrant laborers, 2020 Deccan herald www.deccanherald.com/state/karnataka. https://bangaloremirror.indiatimes.com/bangal ore.

6. Nileena, M. S. 2020 Bangalore workers suffer as Karnataka's response to COVID-marked by delays, inefficiency.

7. National statistics office, 2020. Consumption and investment demand Report.

8. Sethulekshmi, M 2020. Ensure welfare of migrant laborers, projects depend on their return." Deccan Herald. www.deccanherald.com

9. Ranjini Rao,H 2020 Bangalore's Informal Labour Markets. https://www.iimb.ac.in

10. Kundu. Amitabh and Srivastav. Ravi: "Meeting the Food security challenges in India: Ministry of Food and Consumer welfare, Government of India.

11. Sudhindra,D.2020/07https://bengaluru.citizen matters.in/covid-police-role-relief-volunteers.

12. Thomas, 2020, April. Living on the edge: Migrant workers in Bangalore say they are running out of patience. Bangalore Mirror. 